\title{
Front Matter: Volume 7528
}

, "Front Matter: Volume 7528," Proc. SPIE 7528, Color Imaging XV: Displaying, Processing, Hardcopy, and Applications, 752801 (18 January 2010); doi: 10.1117/12.855895

SPIE Event: IS\&T/SPIE Electronic Imaging, 2010, San Jose, California, United SPIE. States 
PROCEEDINGS

IS\&T/SPIE

Electronic

Imaging

SCIENCE AND TECHNOLOGY

\title{
Color Imaging XV: Displaying, Processing, Hardcopy, and Applications
}

\author{
Reiner Eschbach \\ Gabriel G. Marcu \\ Shoji Tominaga \\ Alessandro Rizzi \\ Editors
}

19-21 January 2010

San Jose, California, United States

Sponsored and Published by

IS\&T-The Society for Imaging Science and Technology

SPIE 
The papers included in this volume were part of the technical conference cited on the cover and title page. Papers were selected and subject to review by the editors and conference program committee. Some conference presentations may not be available for publication. The papers published in these proceedings reflect the work and thoughts of the authors and are published herein as submitted. The publishers are not responsible for the validity of the information or for any outcomes resulting from reliance thereon.

Please use the following format to cite material from this book:

Author(s), "Title of Paper," in Color Imaging XV: Displaying, Processing, Hardcopy, and Applications, edited by Reiner Eschbach, Gabriel G. Marcu, Shoji Tominaga, Alessandro Rizzi, Proceedings of SPIE-IS\&T Electronic Imaging, SPIE Vol. 7528, Article CID Number (2010).

ISSN 0277-786X

ISBN 9780819479211

Copublished by

SPIE

P.O. Box 10, Bellingham, Washington 98227-0010 USA

Telephone +1 3606763290 (Pacific Time) · Fax +1 3606471445

SPIE.org

and

IS\&T-The Society for Imaging Science and Technology

7003 Kilworth Lane, Springfield, Virginia, 22151 USA

Telephone +1 7036429090 (Eastern Time) · Fax +1 7036429094

imaging.org

Copyright (c) 2010, Society of Photo-Optical Instrumentation Engineers and The Society for Imaging Science and Technology.

Copying of material in this book for internal or personal use, or for the internal or personal use of specific clients, beyond the fair use provisions granted by the U.S. Copyright Law is authorized by the publishers subject to payment of copying fees. The Transactional Reporting Service base fee for this volume is $\$ 18.00$ per article (or portion thereof), which should be paid directly to the Copyright Clearance Center (CCC), 222 Rosewood Drive, Danvers, MA 01923. Payment may also be made electronically through CCC Online at copyright.com. Other copying for republication, resale, advertising or promotion, or any form of systematic or multiple reproduction of any material in this book is prohibited except with permission in writing from the publisher. The CCC fee code is $0277-786 \mathrm{X} / 10 / \$ 18.00$.

Printed in the United States of America.

Paper Numbering: Proceedings of SPIE follow an e-First publication model, with papers published first online and then in print and on CD-ROM. Papers are published as they are submitted and meet publication criteria. A unique, consistent, permanent citation identifier (CID) number is assigned to each article at the time of the first publication. Utilization of CIDs allows articles to be fully citable as soon they are published online, and connects the same identifier to all online, print, and electronic versions of the publication. SPIE uses a six-digit CID article numbering system in which:

- The first four digits correspond to the SPIE volume number.

- The last two digits indicate publication order within the volume using a Base 36 numbering system employing both numerals and letters. These two-number sets start with 00, 01, 02, 03, 04, 05 , 06, 07, 08, 09, OA, OB ... 0Z, followed by 10-1Z, 20-2Z, etc.

The CID number appears on each page of the manuscript. The complete citation is used on the first page, and an abbreviated version on subsequent pages. Numbers in the index correspond to the last two digits of the six-digit CID number. 


\section{Contents}

vii Conference Committee

ix Abstracts from "Dark Side of Color II" Session

A. Rizzi, Univ. degli Studi di Milano (Italy); G. B. Beretta, Hewlett-Packard Labs. (United States); R. C. Carter, R. Eschbach, Xerox Corp. (United States); J. Gille, Qualcomm Inc. (United States); P. Hubel, Apple Computer, Inc. (United States); J. J. McCann, McCann Imaging (United States); N. Moroney, Hewlett-Packard Labs. (United States); L. D. Silverstein, VCD Sciences, Inc. (United States)

\section{SESSION 1 VISION}

752802 Artist's colour rendering of HDR scenes in 3D Mondrian colour-constancy experiments [7528-01]

C. E. Parraman, Univ. of the West of England (United Kingdom); J. J. McCann, McCann Imaging (United States); A. Rizzi, Univ. degli Studi di Milano (Italy)

752803 Pixel and spatial mechanisms of color constancy [7528-02]

J. J. McCann, McCann Imaging (United States); C. E. Parraman, Univ. of the West of England (United Kingdom); A. Rizzi, Univ. degli Studi di Milano (Italy)

752804 Investigation and analysis of color terms in modern Japanese [7528-03]

S. Tominaga, A. Ono, T. Horiuchi, Chiba Univ. (Japan)

\section{SESSION 2 VISION AND APPLICATIONS}

752805 Color Universal Design: analysis of color category dependency on color vision type [7528-04]

Y. G. Ichihara, Kogakuin Univ. (Japan) and NPO Color Universal Design Organization (Japan); N. Kojima, Kogakuin Univ. (Japan); K. Ito, Univ. of Tokyo (Japan) and NPO Color Universal Design Organization (Japan)

752806 An efficient perceived contrast evaluation model for natural images [7528-05] Q. S. Chen, C.-W. Kim, Inha Univ. (Korea, Republic of)

752807 Age, colors, and ISO standards [7528-06]

F. L. van Nes, ERGONES (Netherlands) and Eindhoven Univ. of Technology (Netherlands)

\section{SESSION 3 COLOR REPRODUCTION AND PRINTING}

752808 Modelling memory colour region for preference colour reproduction [7528-07]

H. Zeng, Hewlett-Packard Co. (United States); R. Luo, Univ. of Leeds (United Kingdom)

752809 Real-time color measurement using active illuminant [7528-08]

S. Tominaga, T. Horiuchi, A. Yoshimura, Chiba Univ. (Japan) 
7528 OA Font rendering on a GPU-based raster image processor [7528-09]

J. L. Recker, G. B. Beretta, I.-J. Lin, Hewlett-Packard Labs. (United States)

7528 OB The development of artists' novel colour palettes for inkjet printing [7528-10]

C. Parraman, Univ. of the West of England (United Kingdom)

7528 OC A joint color trapping strategy for raster images [7528-11]

H. Wang, Qualcomm CDMA Technologies (United States); M. Boutin, Purdue Univ. (United States); J. Trask, Hewlett-Packard Co. (United States); J. P. Allebach, Purdue Univ. (United States)

\section{SESSION $4 \quad$ IMAGE PROCESSING AND APPLICATIONS}

7528 OD Descreening of scanned images [7528-12]

I. V. Kurilin, I. V. Safonov, Samsung Research Ctr. (Russian Federation); H. Lee, S. H. Kim, SAMSUNG Electronics Co., Ltd. (Korea, Republic of)

7528 OE Spectral matching imager with three-phase quadrature detection [7528-13]

A. Kimachi, Osaka Electro-Communication Univ. (Japan); S. Ando, The Univ. of Tokyo (Japan); M. Doi, S. Nishi, Osaka Electro-Communication Univ. (Japan)

7528 OF Automatic white balance method for cellular phone [7528-14] S. K. Jang, K. T. Kim, C.-W. Kim, Inha Univ. (Korea, Republic of)

7528 OG Spectrophotometric and colorimetric analysis of wine for nuances reproduction [7528-15] B. Boisier, A. Mansouri, P. Gouton, LE2I, CNRS, Univ. de Bourgogne (France); P. Trollat, Bureau Interprofessionnel des vins de Bourgogne (France)

\section{SESSION 5 GAMUT MAPPING}

$7528 \mathrm{OH} \quad$ The use of spatially based complexity measures toward color gamut mapping and image resizing [7528-16]

V. Monga, The Pennsylvania State Univ. (United States); R. Bala, C. Fillion, Xerox Corp. (United States)

$7528 \mathrm{Ol} \quad$ Filter methods to preserve local contrast and to avoid artifacts in gamut mapping [7528-17] M. Meili, D. Küpper, Z. Barańczuk, U. Caluori, K. Simon, EMPA (Switzerland)

$7528 \mathrm{OJ} \quad$ Aspects of computational geometry in gamut mapping implementations [7528-18]

D. Küpper, K. Simon, EMPA (Switzerland)

\section{SESSION 6 COLOR SCIENCE}

7528 OK Supplementary dataset for color difference evaluation [7528-19]

A. Trémeau, C. Godau, D. Muselet, Lab. Hubert Curien CNRS, Univ. Jean Monnet (France)

7528 OL LabRGB: evaluation of the weighting factors [7528-20]

F. Nakaya, N. Ohta, Fuji Xerox Co., Ltd. (Japan) 
$7528 \mathrm{OM}$ Evaluation and compensation of fluorescence for spectral imaging of art materials and historical documents [7528-21]

W. A. Christens-Barry, Equipoise Imaging, LLC (United States); K. Boydston, MegaVision, Inc. (United States); R. L. Easton, Jr., Rochester Institute of Technology (United States)

\section{SESSION 7 DISPLAYS}

7528 ON Display color synthesis in the space-time continuum (Invited Paper) [7528-22]

L. D. Silverstein, VCD Sciences, Inc. (United States)

752800 Design principles of wide gamut YCC color encoding space for effective signal sub-sampling [7528-23]

Y. Kwak, Ulsan National Institute of Science and Technology (Korea, Republic of)

$7528 \mathrm{OP}$ Investigating color dependent depth, shape, and motion perception using 3D rendering on monoscopic displays [7528-24]

F. Lebowsky, STMicroelectronics (France)

$75280 Q \quad$ Adaptive color reproduction method to various users' monitor environment in color printer [7528-25]

D.-C. Kim, I.-S. Jang, Kyungpook National Univ. (Korea, Republic of); C.-H. Son, K.-M. Kim, SAMSUNG Electronics Co., Ltd. (Korea, Republic of); Y.-H. Ha, Kyungpook National Univ. (Korea, Republic of)

\section{SESSION 8 THE DARK SIDE OF COLOR}

7528 OV Color naming: color scientists do it between Munsell sheets of color (Invited Paper) [7528-30]

G. B. Beretta, N. M. Moroney, Hewlett-Packard Labs. (United States)

\section{SESSION 9 HALFTONING I}

7528 0X Memory efficient hierarchical error diffusion [7528-32]

Z. He, Z. Fan, Xerox Corp. (United States)

7528 oY Clustered-dot color halftone watermarks using spatial frequency and color separability [7528-33]

B. Oztan, G. Sharma, Univ. of Rochester (United States)

$75280 Z$ Moiré-based autostereoscopic images by duplex printing on transparencies [7528-34]

S.-G. Wang, Xerox Research Ctr. (United States)

\section{SESSION 10 HALFTONING II}

$752810 \quad$ Electro-photographic-model-based halftoning [7528-35]

P. Goyal, M. Gupta, Purdue Univ. (United States); D. Shaked, C. Staelin, M. Fischer, Hewlett-Packard Labs. (Israel); O. Shacham, Hewlett-Packard Indigo Ltd. (Israel); R. Jodra, Hewlett-Packard Co. (United States); J. Allebach, Purdue Univ. (United States) 
$752811 \quad$ Halftone moiré due to imager distortion [7528-36]

O. Bulan, Univ. of Rochester (United States); R. Loce, B. Xu, Xerox Corp. (United States)

752812 Clustered-dot halftoning with direct binary search [7528-37]

M. Gupta, Purdue Univ. (United States); C. Staelin, M. Fischer, Hewlett-Packard Labs. (Israel); O. Shacham, Hewlett-Packard Indigo Ltd. (Israel); R. Jodra, Hewlett-Packard Co. (United States); J. Allebach, Purdue Univ. (United States)

INTERACTIVE PAPER SESSION

752813 Design of transducer structure parameters and materials characteristics analyses for electrical capacitance tomography system [7528-38]

M. Qin, Harbin Univ. of Science and Technology (China)

752814 Color schemes for encoding information in digital maps [7528-39]

R. Zeng, Liming Vocational Univ. (China); H. Zeng, Hewlett-Packard Co. (United States)

Author Index 


\title{
Conference Committee
}

\author{
Symposium Chair \\ Jan P. Allebach, Purdue University (United States) \\ Symposium Cochair \\ Sabine Süsstrunk, Ecole Polytechnique Fédérale de Lausanne \\ (Switzerland) \\ Conference Chairs \\ Reiner Eschbach, Xerox Corporation (United States) \\ Gabriel G. Marcu, Apple Computer, Inc. (United States) \\ Shoji Tominaga, Chiba University (Japan) \\ Alessandro Rizzi, Università degli Studi di Milano (Italy) \\ Program Committee \\ Jan P. Allebach, Purdue University (United States) \\ Scott J. Daly, Sharp Laboratories of America, Inc. (United States) \\ Phil J. Green, London College of Communication (United Kingdom) \\ Roger D. Hersch, École Polytechnique Fédérale de Lausanne \\ (Switzerland) \\ Choon-Woo Kim, Inha University (Korea, Republic of) \\ Michael A. Kriss, Consultant (United States) \\ Fritz Lebowsky, STMicroelectronics (France) \\ Nathan Moroney, Hewlett-Packard Laboratories (United States) \\ Chris Tuijn, Agfa-Gevaert Group (Belgium)
}

Session Chairs

1 Vision

Reiner Eschbach, Xerox Corporation (United States)

2 Vision and Applications

Shoji Tominaga, Chiba University (Japan)

3 Color Reproduction and Printing

Michael A. Kriss, Consultant (United States)

$4 \quad$ Image Processing and Applications

Gabriel G. Marcu, Apple, Inc. (United States) 
5 Gamut Mapping

Choon-Woo Kim, Inha University (Korea, Republic of)

6 Color Science

Choon-Woo Kim, Inha University (Korea, Republic of)

7 Displays

Gabriel G. Marcu, Apple Computer, Inc. (United States)

8 The Dark Side of Color

Alessandro Rizzi, Università degli Studi di Milano (Italy)

9 Halftoning I

Jan P. Allebach, Purdue University (United States)

10 Halftoning II

Reiner Eschbach, Xerox Corporation (United States) 


\title{
The dark side of color II
}

\author{
Alessandro Rizzi ${ }^{\text {a }}$, Giordano B. Beretta ${ }^{\text {b }}$, Robert C. Carter, Reiner Eschbach ${ }^{\text {c }}$, Jennifer Gille ${ }^{\text {d }}$, \\ Paul Hubel ${ }^{\mathrm{e}}$, John J. McCann ${ }^{\mathrm{f}}$, Nathan Moroney ${ }^{\mathrm{b}}$, Louis D. Silverstein ${ }^{\mathrm{g}}$ \\ ${ }^{a}$ DTI - Università degli Studi di Milano, Italy \\ ${ }^{\mathrm{b}}$ HPLabs, USA \\ ${ }^{\mathrm{c}}$ Xerox Corp., USA \\ ${ }^{\mathrm{d}}$ Qualcomm, USA \\ e Apple, USA \\ ${ }^{\mathrm{f}}$ McCann Imaging, USA \\ ${ }^{\mathrm{g}}$ VCD Sciences, Inc., Scottsdale, Arizona
}

\begin{abstract}
This year, at Electronic Imaging 2010, will be held for the second time, as part of the "Color Imaging XV: Displaying, Hardcopy, Processing, and Applications" conference, the special session entitled, "Dark Side of Color". This session aims at introducing innovative thinking, and discussion from experts working in a wide range of disciplines related with color, to foster ideas and stimulate about open issues and common misunderstanding in color science and technology. It is composed by a limited number of invited short presentations that are presented as summaries in this paper together with an overall description of the session point of view.
\end{abstract}

Keywords: Dark side of color, Color, Color models, Color teaching, Colorimetry, Color related phenomena

\section{WHAT THIS SESSION IS ABOUT}

What is the dark side of color?

Color is a very complex phenomenon that cannot be explained with only physics principles. The human vision system is what transforms the physical stimuli into the colors we see.

Color related topics are sometime taught and communicated without presenting their inner complexity, their limits and the simplifications that sometime are at their base. A-critically following pre-defined "recipes" can lead to the risk of loosing the overall framework and consequently a complete understanding of the chosen technique.

Classic colorimetric methods, specifically designed to deal with color in aperture mode (isolated, out of visual context), have become dominant in digital color science and technology. Their use has been extended to deal with a great variety of situations in which color is considered inside a visual context, thus outside its initial scope. Color science is facing this transitional evolution in order to deal with color in context and appearance, but without substantial changes in their original foundation.

There is a need for widening the scientific debate and discuss about paradigms. This can be achieved by, for example, new questions, different attention for details; information in the margins that so far are often discounted or overlooked. These aspects are what we consider to be the "dark side of color".

The invited speakers of this section have been asked to stimulate ideas and discussions on the needs and the characteristics of possible alternative approaches and/or point of view. This session aims at suggesting paradigm shifts, lateral thinking and bottom up experimentation by re-addressing the current state of the evolving situation in color in sciences, arts and technologies. 
Following these principles, every speaker has chosen a topic of his/her preference and presents open issues and problems in a short 15-minutes presentation. The presentation abstracts are reported in the following sections to give the reader a glance on the discussed topics.

We would like to stress that basically no answers are expected to arise from the presentations of this session, but more likely questions and perspective shifts.

\section{THE SPEAKERS}

Here are the abstracts of the speakers that will participate at this second edition of the session of the Dark Side of Color. They are listed in alphabetical order.

\section{1 "Color naming: color scientists do it between Munsell Sheets of Color" Giordano Beretta and Nathan Moroney}

With the advent of high dynamic range imaging and wide gamut color spaces, gamut mapping algorithms have to nudge image colors much more drastically to constrain them within a rendering device's gamut. Classical colorimetry is concerned with color matching and the developed color difference metrics are for small distances. For larger distances, categorization becomes a more useful concept. In the gamut mapping case, lexical distance induced by color names is a more useful metric, which translates to the condition than a nudged color may not cross a name boundary. The new problem is to find these color name boundaries. We compare the experimental procedures used for color naming by linguists, ethnologists, and color scientist and propose a methodology that leads to robust repeatable experiments.

\section{2 "Size matters: The problem of color-difference estimation for small visual targets" Robert C. Carter and Louis D. Silverstein}

A longstanding problem in color science is the accurate estimation of color differences for visual targets of small angular subtense. For instance, "What is the magnitude of a half-degree color difference that will be as discriminable as a given two-degree color difference?" Or, "What is the reduced angular subtense (or increased distance) at which two visual fields of given colors will become appreciably less discriminable than they were at larger subtense (or smaller distance)?" Past attempts at solving this problem have been specific to a particular color difference equation and, as such, the work lost relevance as improved color difference formulae were developed. This presentation proposes a structural model based upon the response of retinal cone cells to small-subtense target images scattered by the ocular media. The method is demonstrated to be applicable without alteration to very different contemporary color difference equations, to be practical with a wide range of surround intensities, and to have high correlation with human search performance involving small color targets on an electronic information display.

\section{3 “Controlled versus uncontrolled viewing conditions in color evaluation" Reiner Eschbach}

A large part of the information we are gathering on Human Perception comes from carefully designed controlled visual experiments. In these experiments the experimental parameters are carefully controlled and any extraneous influence is reduced or eliminated. But what, if the experiment does not agree with the noisy observations in the real world ? Are there ways to identify the source of the problem ? Actually, a more interesting question is: where do I look for the noise source. Which data points do I mistrust and how do I design an experiment to distinguish ? This talk describes our current hypothesis in light of such a contradiction in our own experiments. 


\section{4 “Mind over Matter" Jennifer Gille}

We generally treat color as a separable property of objects. The physiological evidence of color channels in early vision would seem to support this view. Still, many color phenomena belie this simple idea. What does this mean for our characterization of color?

\section{5 “Globalization of color" Paul Hubel}

Digital image rendering brings the ability to apply complex color and tone correction algorithms. One of the more difficult aspects of newer rendering techniques is the balance between global and some kind of local correction. In the case of computer vision where the reproduction of surface color is desired, local corrections that can separate out the illumination is desirable. In photography, however, the characteristics of the illumination are fundamental to the scene and removal can destroy not only the artistic intent but also move the rendering further from the scene perception. In terms of tone this kind of thing can remove depth perception - in faces, for example - and in color this can turn warm sunset illumination into cold noonday sun. Clearly some local manipulation is necessary, particularly for HDR mapping. Examples will be shown and the challenge for the future is getting the balance between global and local influence to match both perception and photographic preference.

\section{6 "The appearance of illusions and the delusion of reality" John McCann}

Physicists born in the 18th century still influence our impressions of reality. Take for example, the work at the Royal Institution, London around 1800. Sir Humphrey Davy and Josiah Wedgwood developed a precursor to silver-halide photography. Thomas Young taught at the Royal Institution at the time and proposed that three types of retinal receptors at the same location could explain our color response to all visible wavelengths. It is tempting to think that vision behaves the same as silver-halide film. We tend to think that the response of a single pixel can successfully model the response of every pixel in the entire image, with curious exceptions, that we call "illusions".

Webster defines illusion as the state, or fact, of being intellectually deceived or misled. The usage for visual test targets makes sense if, and only if, we assume that human vision must behave the same as photographic film. However, by 1800 there were shrewd observations to the contrary by da Vinci, von Guericke, Count Rumford, and many others. They showed that vision was different from film. All the neurophysiology of the second half of the 20th century has shown the visual pathway is a sequence of spatial operators. These operators compare the response of one part of the retinal image with another. Color is the result of spatial comparisons of all the pixels in the scene. The pixel model of human color vision is a delusion.

For vision, we need to free our thinking from the single-pixel models of physicists. If we measure a display, the quantum catch of a single pixel can describe the light. However, if we look at a display, we apply our spatial imageprocessing pathway to the image on our retinas. Our spatial transformation of retinal images is the reality of human color vision. 
Downloaded From: https://www.spiedigitallibrary.org/conference-proceedings-of-spie on 26 Apr 2023

Terms of Use: https://www.spiedigitallibrary.org/terms-of-use 